\title{
Effect of Culture Age on Protective Potency of a Vaccine Against Bovine Ringworm Prepared of Trichophyton Verrucosum
}

\author{
A. RYBNIKÁR̆, J. CHUMELA, V. VRZAL \\ Bioveta Plc., Ivanovice na Hané, Czech Republic
}

Received March 19, 2001

Accepted February 13, 2002

\section{Abstract}

Rybnikář A., J. Chumela, V. Vrzal: Effect of Culture Age on Protective Potency of a Vaccine against Bovine Ringworm Prepared of Trichophyton verrucosum. Acta Vet. Brno 2002, 71: 51-53.

Calves vaccinated with live vaccine against bovine ringworm prepared of a two-week-old culture of Trichophyton verrucosum showed satisfactory protection against experimental dermatophytic infection. Vaccines prepared of cultures of the same strain aged 37, 65, or 92 days were less effective.

Vaccination, Trichophyton verrucosum, challenge

Good efficacy of vaccination in the control of ringworm has been confirmed by several authors (Sarkisov 1976; Gudding and Lund 1995). Remarkable results were obtained with vaccines containing live cultures of dermatophytes (Sarkisov and Kolesnikov 1989; Rybnikář et al. 1996). Detailed descriptions of technological procedures for such vaccines are usually subject to confidentiality by manufacturers. One of the relevant, but only seldom given, parameters is the age of cultures of vaccine strains used for the manufacture. No data on the effects of culture age on the efficacy of vaccines were found in available literature and therefore this factor became the object of our investigations.

\section{Materials and Methods}

Experimental design

The experiment was conducted in a ringworm-free herd of Bohemian Red Pied cattle. Calves aged 21 to 42 days were divided into one control and four experimental groups. The calves of the experimental groups were vaccinated twice at a 12-day interval by intramuscular administration of live freeze-dried vaccines prepared of Trichophyton verrucosum cultures aged 14 to 92 days.

Vaccines

The vaccines were prepared of 14-, 37-, 65- or 92-day-old cultures of T. verrucosum. The strain was propagated and the vaccines were prepared by the standard confidential procedure. The vaccines were distributed into vials at equal doses of microconidia of the vaccine strain for all the variants, and freeze-dried. Vials containing the vaccines were sealed in vacuum. The vaccines were reconstituted in physiological saline immediately before use.

Challenge test

All the vaccinated calves (Groups 1 to 4 ) and the non-vaccinated control group were challenged by epicutaneous inoculation of $7 \times 10^{6} \mathrm{CFU}$ of $T$. verrucosum onto a sheared and gently scarified skin area of $10 \times 10 \mathrm{~cm}$ on the right flank side one month after the second vaccination.

Evaluation of findings

The calves were observed twice a week for a period of 34 days after the challenge. The challenge site was examined visually and by palpation considering possible dissemination of mycotic infection and development of clinical manifestations. Crusts and scales from clinically positive calves and swabs and hair samples from the challenge sites of clinically normal calves were collected on post-challenge day 34 . All the samples were examined microscopically and by culture (Rybnikář 1992).

Address for correspondence:

RNDr. Alois Rybnikár̆,

Bioveta, a.s.

Komenského 212, 68323 Ivanovice na Hané
Czech Republic
Phone: +420507363321

Fax: +420 507363294

http://www.vfu.cz/acta-vet/actavet.htm 


\section{Results}

The results are summarised in Table 1. Calves immunised with the vaccine prepared of a 14-day-old culture developed small skin lesions which disappeared spontaneously within a short time. All the calves of this group were free of clinical manifestations at the end of the observation period of 34 days. Two of the 18 calves vaccinated with the 37 -day-old culture, 2 of the 15 calves vaccinated with the 65 -day-old culture, and 6 of the 15 calves vaccinated with the 92-day-old culture of $T$. verrucosum developed skin lesions which persisted throughout the observation period.

Table 1

Protective efficacy of vaccines against ringworm prepared of culture of various ages

\begin{tabular}{|c|c|c|c|c|c|c|c|c|c|c|c|c|c|c|c|c|c|c|c|c|c|}
\hline \multirow{3}{*}{ Experimental group } & \multirow{3}{*}{$\begin{array}{l}\text { No. of } \\
\text { calves }\end{array}$} & \multicolumn{20}{|c|}{ Skin mycotic changes after challenge, days after challenge } \\
\hline & & \multicolumn{5}{|c|}{$14^{\text {th }}$ day } & \multicolumn{5}{|c|}{$21^{\text {st }}$ day } & \multicolumn{5}{|c|}{$27^{\text {th }}$ day } & \multicolumn{5}{|c|}{$34^{\text {th }}$ day } \\
\hline & & - & \pm & + & ++ & +++ & - & \pm & + & ++ & +++ & - & \pm & + & ++ & +++ & - & \pm & + & ++ & +++ \\
\hline $\begin{array}{l}1^{\text {st }} \text { group - vaccinated } \\
\text { calves } \\
\text { vaccine prepared of } \\
\text { 14-day-old culture }\end{array}$ & 18 & 10 & 4 & 4 & 0 & 0 & 16 & 2 & 0 & 0 & 0 & 17 & 1 & 0 & 0 & 0 & 18 & 0 & 0 & 0 & 0 \\
\hline $\begin{array}{l}2^{\text {nd }} \text { group - vaccinated } \\
\text { calves } \\
\text { vaccine prepared of } \\
37 \text {-day-old culture }\end{array}$ & 18 & 8 & 5 & 4 & 1 & 0 & 12 & 2 & 2 & 2 & 0 & 14 & 1 & 1 & 2 & 0 & 15 & 1 & 2 & 0 & 0 \\
\hline $\begin{array}{l}3^{\text {rd }} \text { group - vaccinated } \\
\text { calves } \\
\text { vaccine prepared of } \\
65 \text {-day-old culture }\end{array}$ & 15 & 8 & 5 & 2 & 0 & 0 & 11 & 2 & 1 & 1 & 0 & 13 & 0 & 0 & 2 & 0 & 13 & 0 & 0 & 2 & 0 \\
\hline $\begin{array}{l}4^{\text {th }} \text { group - vaccinated } \\
\text { calves } \\
\text { vaccine prepared of } \\
\text { 92-day-old culture }\end{array}$ & 15 & 7 & 2 & 4 & 2 & 0 & 9 & 0 & 3 & 3 & 0 & 9 & 0 & 0 & 6 & 0 & 9 & 0 & 3 & 3 & 0 \\
\hline $\begin{array}{l}5^{\text {th }} \text { group-non-vaccinated } \\
\text { control calves }\end{array}$ & 15 & 1 & 4 & 9 & 1 & 0 & 0 & 0 & 3 & 3 & 9 & 0 & 0 & 6 & 6 & 3 & 0 & 0 & 8 & 5 & 2 \\
\hline
\end{tabular}

- free of mycotic skin lesions; \pm small skin lesions (scales, papillae) ++ solitary skin lesions; ++ mycotic lesions covering more than $1 / 4$ of the inoculated area; +++ mycotic lesions covering more than $1 / 2$ of the inoculated area.

The calves of the control group developed serious skin lesions at the challenge site that persisted throughout the observation period.

No disseminated mycotic lesions or other clinical manifestations were seen in any of the control or experimental calves.

The results of culture tests and microscopic findings were positive only in calves developing clinical ringworm.

\section{Discussion}

Data on the dependence of the quality and complexity of immune responses on the developmental stage of fungi were published by Weigl (1987). The author identified tips of hyphae as the immunologically most reactive structures and emphasized benefits of young fungal cultures for the production of vaccines, but failed to present specific data. Sarkis ov (1981) identified microconidia of dermatophytes as the most effective structure for the induction of immunity against dermatophyte infections. Unlike hyphae, microconidia are highly resistant to freeze-drying (Nikiforov 1976; Rybnikár et al. 1983) and have become the basic component of current commercial freeze-dried vaccines against mycotic infections. 
Live vaccines containing microconidia as the major active component were used also in our experiment. The vaccines were prepared of a $T$. verrucosum strain known for its good immunogenicity (Rybnikář et al. 1991). This characteristic was confirmed by results of our experiment that demonstrated protective effects of the tested vaccines by comparison with non-vaccinated control animals. However, the protective effect depended on the age of the fungal culture used for vaccine production. The best results were obtained with the vaccine prepared of a 14-day-old culture which showed protective effect comparable with that of vaccines tested in our earlier experiments (Rybnikár et al. 1993). The efficacy of vaccines decreased with advancing age of the culture. The decrease in efficacy may have been associated with a change in growth rate, development of pleomorphic degeneration, and/or a change in microscopic structure as phenomena observed often during prolonged culture of dermatophytes.

The results indicate that immunogenicity of fungal antigens depends on the age of the culture at the time of vaccine production. Similar studies in other cultures of dermatophytes might yield new information relevant both to theoretical studies and to practical application not only in the area of vaccinology.

\section{Protektivní účinnost vakcíny proti trichofytóze skotu připravené z kultury Trichophyton verrucosum různého stáří}

Živá vakcína proti trichofytóze skotu obsahující čtrnáctidenní kulturu Trichophyton verrucosum prokázala $\mathrm{v}$ čelenžním pokusu na telatech vyhovující protektivní účinnost. Účinnost dalších vakcín připravených ze stejného vakcinačního kmene stáří 37, 65, resp. 92 dnů byla nižší.

\section{References}

GUDDING, R., LUND, A. 1995: Immunoprophylaxis of bovine dermatophytosis. Can. Vet. J. 36: 302-306

NIKIFOROV, L. I. 1976: Immunogenous activity testing of experimental series of dry anti-trichophytosis vaccine LTF-130. Bjul. Vses. Ord. Lenina Inst. Eksper. Vet. 25: 11-13 (in Russian)

RYBNIKÁ ̌́, A. 1992: Cross-immunity in calves after vaccination against trichophytosis. Acta vet. Brno 61:189194

RYBNIKÁR̆, A., CHUMELA, J., VRZAL, V., KRUPKA, V. 1991: Immunity in cattle vaccinated against ringworm. Mycoses 34: 433-436

RYBNIKÁŘ, A., DITRICH, O., PYTELA, F. 1983: Lyophilization of some cultures of dermatophytes. Czech Mycol. 37: 93-98 (in Czech)

RYBNIKÁR̆, A., VRZAL, V., CHUMELA, J. 1993: Vaccination of young calves against trichophytosis. Acta vet. Brno 62: 55-61

RYBNIKÁŘ, A., VRZAL, V., CHUMELA, J., HEJTMÁNEK, M., WEIGL, E. 1996: Vaccination of cattle against trichophytosis using the Czech vaccines. J. Mycol. Méd. 6: 93-94

SARKISOV, A. CH. 1976: Prophylaxie spécifique de la Trichophytose des jeunes bovins. Bull. Off. Int. Epiz. 85 : 481-488

SARKISOV, A. CH. 1981: Dermatomikozy životnych i sovremennyje sredstva ich profilaktiki. Bjul. Vses. Nauč. Issl. Inst. Eksp. Vet. 42: 3-10 (in Russian)

SARKISOV, A. CH. - KOLESNIKOV, A. Y. 1989: Osnovnyje puti iskorenenija dermatomikozov. Veterinarija (Moskva) 12: 36-38 (in Russian)

WEIGL, E. 1987: Immunology in dermatophytoses. Čs. Epidem. 36: 308-319 (in Czech) 